\title{
Experimental skin wound treatment with Copaifera langsdorffii Desf Kuntze (Leguminosae) extract and oil-resin in horses
}

\section{Tratamento experimental de feridas cutâneas com extrato e óleo resina de Copaifera langsdorffii Desf Kuntze (Leguminosae) em equinos}

\author{
Débora Perrone Kauer ${ }^{1}$; Juliana de Moura Alonso'; Lucas Fernando Sergio Gushiken²; Marivane Lemos; \\ Carlos Roberto Padovani²; Celso Antonio Rodrigues ${ }^{1}$; Ana Liz Garcia Alves ${ }^{1}$; Marcos Jun Watanabe ${ }^{1}$; \\ Jairo Kenupp Bastos ${ }^{3}$; Cláudia Helena Pellizzon²; Carlos Alberto Hussni1* (D) \\ ${ }^{1}$ Universidade Estadual Paulista, Faculdade de Medicina Veterinária e Zootecnia, Botucatu - SP, Brazil \\ ${ }^{2}$ Universidade Estadual Paulista, Instituto de Biociências, Botucatu - SP, Brazil \\ ${ }^{3}$ Universidade de São Paulo, Faculdade de Ciências Farmacêuticas de Ribeirão Preto, Ribeirão Preto - SP, Brazil
}

\begin{abstract}
Copaifera langsdorffii is a Brazilian native plant that is used for wound healing or as an anti-inflammatory agent. Non-healing wounds are an important health problem, particularly in horses, because they can cause the animal invalidity or even lead to death. In addition, horses respond to skin wounds with chronic inflammatory response and intense wound granulation, thereby delaying the healing process. By this way, our aim was to evaluate the healing potential of Copaifera langsdorffi $i$ hydroalcoholic extract (HE) and oil-resin creams (OR) in horse skin wounds. Four wounds were performed bilaterally in the lumbar region of six horses with a $2 \mathrm{~cm}$ punch and treated daily with the respective treatments: saline solution, vehicle, $10 \% \mathrm{HE}$ creams or $10 \%$ OR cream. Daily planimetry analyses were performed to measure the wound area and clinical parameters. In four different experimental periods $(3,7,14$ and $21 \mathrm{~d}$ ), wound biopsies were removed and used for microscopic analyses. SS wounds presented a significant small area at day 3 and 7, OR wounds presented significant small area in comparison with $\mathrm{HE}$ at $14 \mathrm{~d}$, and no significant difference was observed between treatments at $21 \mathrm{~d}$. A better microscopic and clinical healing activity of HE and OR was identified in comparison with the controls. The OR group showed better healing quality, specifically after $7 \mathrm{~d}$ of treatment. Therefore, Copaifera langsdorffi formulations demonstrated their wound healing potential in horse skin lesions, exhibiting an improvement of the macro- and microscopic parameters.
\end{abstract}

Keywords: Copaiba. Healing. Phytotherapy.

\section{RESUMO}

Copaifera langsdorffii é uma planta nativa brasileira usada para cicatrização de feridas e como agente anti-inflamatório. As feridas que não cicatrizam são um importante problema de saúde em equinos, devido à possibilidade de afastamento da carreira atlética ou até mesmo levar à morte. Além disso, os cavalos respondem às feridas com resposta inflamatória crônica e intensa granulação, atrasando o processo cicatricial. Dessa forma, o presente trabalho avaliou o potencial do extrato hidroalcoólico (EH) e cremes de óleo resina (OR) de Copaifera langsdorffii em feridas cutâneas de equinos. Quatro feridas de $2 \mathrm{~cm}$ foram realizadas bilateralmente na região lombar de seis equinos e tratadas diariamente com: solução salina, veículo, creme EH 10\% ou creme OR 10\%. Diariamente foi efetuada a análise macroscópica das feridas e planimetria para mensurar a área da ferida. Em quatro períodos experimentais diferentes (3, 7, 14 e 21 dias), as biópsias foram realizadas e utilizadas para análises microscópicas. As análises microscópica e clínica indicaram melhor resposta cicatricial nas feridas tratadas com HE e OR em comparação com os controles. O grupo OR apresentou melhor qualidade de cicatrização, especificamente após sete dias de tratamento. Portanto, as formulações de Copaifera langsdorffii utilizadas apresentaram potencial de cicatrização de feridas em lesões de pele de cavalo, exibindo uma melhora nos parâmetros macro e microscópicos.

Palavras-chave: Copaíba. Cicatrização. Fitoterapia. 
Correspondence to:

Carlos Alberto Hussni

Universidade Estadual Paulista, Faculdade de Medicina

Veterinária e Zootecnia

CEP: 18618-681, Rua Prof, R. Dr. Valter Maurício Corrêa, s/n,

Botucatu - SP, Brazil

e-mail: cahussni@fmvz.unesp.br

Received: January 28, 2020

Approved: June 29, 2020

How to cite: Kauer DP, Alonso JM, Gushiken LFS, Lemos M, Padovani CR, Rodrigues CA, Alves ALG, Watanabe MJ, Bastos JK, Pellizzon CH, Hussni CA. Experimental skin wound treatment with Copaifera langsdorffii Desf Kuntze (Leguminosae) extract and oil-resin in horses. Braz J Vet Res Anim Sci. 2020;57(3): e166095. https://doi. org/10.11606/issn.1678-4456.bjvras.2020.166095

\section{Introduction}

Copaifera langsdorffi Desf Kuntze (Leguminosae) is a native plant from the tropical regions of Latin America and West Africa, which can be found from North to Southeast Brazil, primarily in the states of Amazonas, Pará and Ceará (Veiga \& Pinto, 2002). Copaifera langsdorffii is particularly important in Brazil because it is widely distributed throughout the country and is used in popular and indigenous knowledge as a healing and anti-inflammatory agent (Corrêa, 1984; Veiga \& Pinto, 2002). Due to its use in popular medicine since the $16^{\text {th }}$ century, studies have reported several biological activities related to the Copaifera langsdorffii oil-resin and leaves extract, as well as skin wound healing (Gushiken et al., 2017a; Lemos et al., 2015; Masson-Meyer et al., 2013), anti-microbial activity (Abrão et al., 2015), gastrointestinal diseases treatments (Gomes et al., 2007; Lemos et al., 2015; Paiva et al., 2002), antiedematogenic (Furtado et al., 2015), antinociceptive (Gomes et al., 2007) and urolithiasis treatment (Brancalion et al., 2012; Oliveira et al., 2013). However, there are few studies reporting copaiba effects in horse skin wound healing (Lucas et al., 2017).

The study of cutaneous wound healing is an important research field in veterinary medicine, particularly in horses. From the discontinuity of skin integrity, there is the beginning of the cicatricial response to re-establish the protective barrier that separates the organism from the external environment, thereby promoting a series of mechanisms, such as coagulation, inflammation, reepithelialization, granulation, angiogenesis, lesion contraction and extracellular matrix remodelling (Rittie, 2016; Tziotzios et al., 2012). Due to biological factors, such as a reduction of blood supply, excessive granulation and chronic inflammation, distal lesions in equine limbs present retardation in healing mechanisms (Schwartz et al., 2002; Spaas et al., 2013). Chronic inflammation causes excessive granulation, delaying reepithelialization and remodelling of the extracellular matrix, which delays wound closure and increases the risk of possible infections, which may lead to animal incapacitation and death (Funkquist \& Obel, 1979; Spaas et al., 2013).

Due to the importance of horses in human life, the delay of wound healing in this species, the economic costs of the treatments and the ineffectiveness of conventional treatments, it is necessary to identify new therapeutic strategies and products to accelerate wound retraction. By this way, the use of natural products (Gál et al., 2009; Rennert et al., 2013), such as plants or derived molecules, have been successfully tested in wound healing (Cetin et al., 2013; Morin et al., 2012; Roy et al., 2012; Tarameshloo et al., 2012; Upadhyay et al., 2013).

Therefore, this study evaluated the healing potential of topical formulations containing Copaifera langsdorffii hydroalcoholic extract of leaves and oil-resin extracted from bark in the cutaneous lesions of horses.

\section{Material and Methods}

\section{Animals}

This study was approved by the Ethics Committee on the Use of Animals of the Institute of Biosciences of Botucatu - UNESP (CEUA - IBB 419/12). Six healthy mixed-breed adult horses of both genders and with an average age of 8 years were used. The animals were kept in individual stalls, fed with coast cross grass hay, and provided with water ad libitum.

The health status of all included horses was accessed by clinical and laboratory evaluation (WBC count and feces examination).

\section{Skin wounds experimental induction}

After 12-h fasting and xylazine hydrochloride $(0.5 \mathrm{mg} / \mathrm{kg})$ intravenous administration, horses were clipped covering a region of approximately $35 \mathrm{~cm}$, in which the cranial limit of the clipped area was the spinous processes of the $10^{\text {th }}$ thoracic vertebra, and the caudal limit was the spinal processes of the $4^{\text {th }}$ lumbar vertebra. The clipped area extended bilaterally parallel to the axis of the vertebral spine by $15 \mathrm{~cm}$ in width on the region of the longissimus dorsi muscle. Antisepsis of the region was performed with $2 \%$ degermant chlorhexidine digluconate followed by alcoholic $0.5 \%$ chlorhexidine digluconate. 
Skin marking of the region for wounds was performed using a pen for projector film, with markings being spaced $5 \mathrm{~cm}$ apart between the wounds. Local infiltrative anaesthesia was performed with $2 \%$ lidocaine without a vasoconstrictor. Using a punch of $2 \mathrm{~cm}$ in diameter, four circular wounds were performed on each side of the animal (one for each treatment). The size of the wounds was based in previous descriptions (Hussni et al., 2010; Gushiken et al., 2017a). The right side was intended for macroscopic observations, planimetry and observation of total healing time. Left-sided wounds were used for biopsy collection for histopathological analysis according to the protocol described by Hussni et al. $(2004,2010)$.

The study was randomized. The choice of the horses for each treatment sequence was aleatory. The sequence of the treatments was arranged in different sequences in each animal and were combined alternately in the craniocaudal direction, to avoid the influence of the location of the lesions on the results. This combination resulted in an equitable distribution of treatments by region. The sequence for each animal was used bilaterally (Table 1).

\section{Experimental groups}

The wounds were subjected to the following treatments: Saline solution $0.9 \%$ - control (SS); Base cream (Lanette) vehicle (BC); Base cream containing hydroalcoholic extract from 10\% copaiba leaves (HE); Base cream containing oilresin extracted from 10\% copaiba bark (OR).

\section{Pain assessment}

Previously to the macroscopic examination of the wound beds, a digital palpation of the perilesional region was performed to evaluate the presence of pain sensibility. The degree of sensibility was scored in 0 -absent; 1 - present in one of the lesions; 2-present in two or more wounds. The horses behavior was also evaluated to identify the presence of pain. For this, food intake and the position of the horse in the stall was used.

Perilesional oedema was evaluated in addition to pain assessment and was graduated in 3 scores: 0 -absent; 1 - mild; 2 - severe. The frequency of the scores of pain and edema at day $1,3,7,14$ and 21 was evaluated between treatments. The distribution of the frequencies was realized using Proc Freq, and the analysis was performed using SAS Version 9.1 (SAS Institute Inc., Cary, NC, USA).

No anti-inflammatory drugs were administered after the lesions were performed to minimize negative effects on healing. The administration of dipyrone $(30 \mathrm{mg} / \mathrm{Kg})$ was reserved in case of pain at the wound site.

\section{Macroscopic analysis}

The wounds were treated daily with topical application of the products directly on the lesion. Prior to the application of the respective treatments, the wounds were cleaned with $0.9 \%$ saline solution. The treatment was started immediately after the wounds were performed.

Macroscopic analysis was performed by two trained and independent evaluators. In cases of discordance, a third evaluator was actioned. Photo documents were obtained at the time of the macroscopic evaluations for each treatment performed on each animal. A distance of $20 \mathrm{~cm}$ was standardized for the photographs. In addition, daily measurement of the lesion areas was performed using planimetry, with the contour of its edges being drawn by overlapping in transparent plastic sheets and a marker pen. The area of the lesion was measured using specific software from the ellipse area formula (Area $=\pi^{*}$ smaller radius ${ }^{\star}$ larger radius).

Treatments were applied immediately after the macroscopic analysis.

\section{Microscopic analysis}

All the wounds in the left side of the horses were subjected to the biopsies that were performed on days 3, 7, 14 and 21 of the treatment. Samples were collected using a scalpel blade (n.15), alternately between the ends of the rays at the edges of the wounds, measuring approximately $5 \mathrm{~mm}$ in length and $3 \mathrm{~mm}$ in width, covering the transition region of the wound bed and integrated skin (Figure 1). The samples were fixed in $80 \%$ alcohol, formaldehyde, and acetic acid solution (18:2:1) and processed for morphological and morphometric analyses. Next, 5 - $\mu \mathrm{m}$-thick blades were stained with hematoxylin and eosin

Table 1 - Wound treatment distribution in the horse lumbar region (Botucatu- SP, Brazil, 2014)

\begin{tabular}{lcccc}
\hline & Wound 1 & Wound 2 & Wound 3 & Wound 4 \\
\hline Animal 1 & SS & BC & HE & OR \\
Animal 2 & OR & SS & BC & HE \\
Animal 3 & HE & OR & OR & BC \\
Animal 4 & BC & HE & HE & SS \\
Animal 5 & SS & BC & BC & OR \\
Animal 6 & OR & SS & HE \\
\hline
\end{tabular}

SS - saline solution; BC - base cream; HE - hydroalcoholic extract; OR - oil-resin. 
(HE) to visualise the cellularity and quantify the number of vessels (Gushiken et al., 2017a). All morphological analyses were performed in 5 random fields for each sample with 40x lens and the cellSens Standard software (Olympus, USA), with a total analysis area of $100.000 \mathrm{\mu m}^{2} /$ slide. Measurements were performed using AVSoft BioView 4.0 software.

\section{Statistical analysis}

Parametric data were expressed as the mean \pm standard deviation of the mean and one-way ANOVA was performed followed by Tukey's test or Dunn's Multiple Comparison

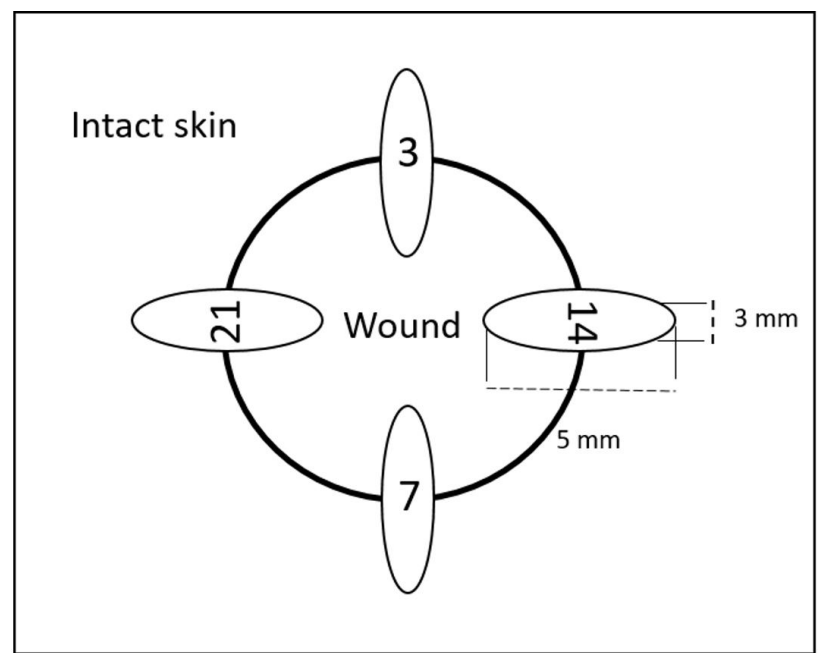

Figure 1 -Sequence of biopsy performed in horses for evaluating skin lesions, on days 3, 7, 14 and 21 of treatment. The fragments were removed in the form of an ellipse, where the longest length was $5 \mathrm{~mm}$ and width $3 \mathrm{~mm}$.
Test with $\mathrm{p}<0.05$. Analyses were performed using GraphPad Prism software.

\section{Results}

Regarding the lesion induction procedure, there were no complications that would cause discomfort and / or inflammation for the removal of any of the animals from the experimental groups. No horses presented pain at the perilesional lesion, reduced food intake or presented a behavior compatible with pain. No analgesics were administered. No difference of pain sensibility or local edema was observed between treatments. A mild perilesional edema was observed in all lesions in the first $2 \mathrm{~d}$ of treatment. The frequency of the scores of pain sensibility was the same between treatments. All the lesions presented score 0 for pain at all time points. Regarding edema, a score 1 was observed in all lesions at day 1 , a score 1 was maintained in the lesions treated with SS at day 3, and a score 0 was identified for the other treatments at day 3, and to all treatments at day 7 and 14 .

The incorporation of the active principles into the Lanette cream provided greater physicochemical stability to the product, presenting low oiliness, moisturizing action, emollient and maintenance of the chemical structure of the active principles.

The wounds showed expected bleeding at the time of the accomplishment (Figure 2A-D), followed by the formation of a dark reddish crust consisting of a dehydrated and non-adhered hemostatic clot. Between the second and
SS

0

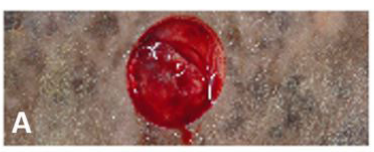

3

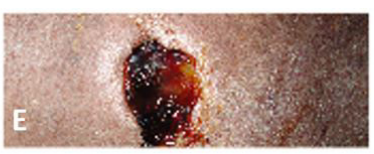

7

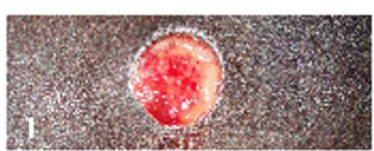

14

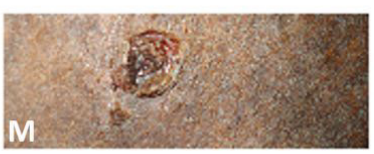

21

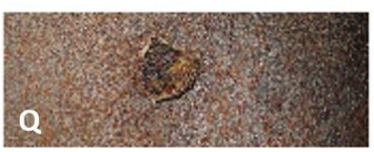

BC
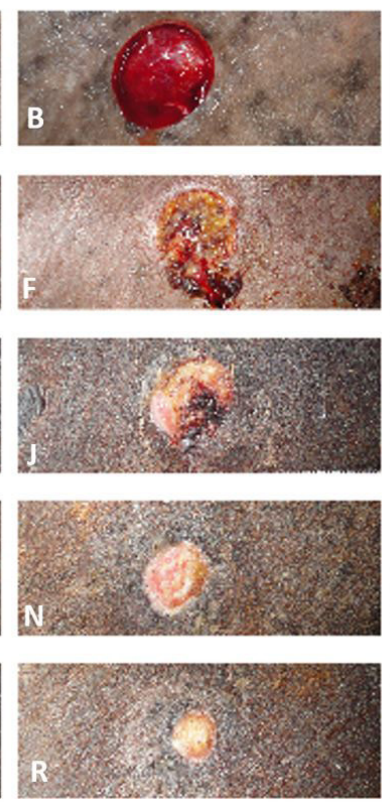

HE
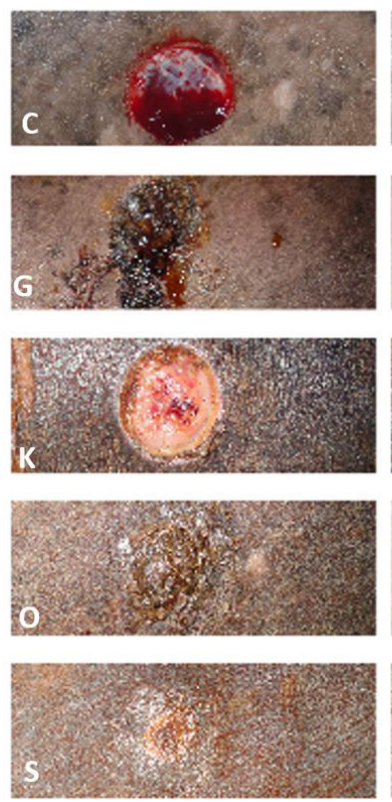

OR
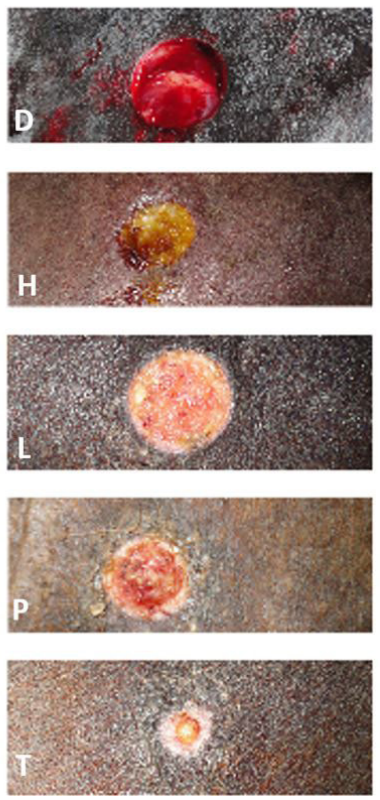

Figure 2 - Treated horse wounds at different experimental periods (0, 3, 7, 14 and $21 \mathrm{~d})$. Presence of initial hemorrhage (A-D); presence of a hemostatic crust, serous exudate and edema of the border of the wounds (E-H), specifically (E-F); reduction of exudate and perilesional edema, visualization of granulation (I-L); significant retraction of the lesions (Q-T), presence of the fibrin crust (Q). SS - saline solution; BC - base cream; HE - hydroalcoholic extract; OR - oil-resin. 
third day, these wounds crusts were not adhered and were removed during daily treatment, except for those treated with physiological solution, which remained firmly adhered.

On the third day of treatment, the lesions showed intense exudation and perilesional edema, particularly in wounds treated with saline solution (Figure $2 \mathrm{E}-\mathrm{H}$ ). In the lesions treated with $\mathrm{HE}$, there was no perilesional edema, but the presence of exudates was observed (Figure 2G). The wounds treated with the oil-resin were drier and did not present an apparent crust (Figure $2 \mathrm{H}$ ).

Biopsies performed on the third day showed many typical lymphocytic infiltrate cells, and abundant cellular debris could still be observed (Figure 3A-D).

The wounds treated with $\mathrm{BC}, \mathrm{HE}$ and $\mathrm{OR}$ presented more persistent serous exudate production with the formation of a discrete yellowish, thin and adherent crust from the $7^{\text {th }}$ day of treatment (Figure $2 \mathrm{~J}-\mathrm{L}$ ), while the wounds of the control group (SS) presented serous exudate only until the third day of treatment (Figure 2E and I). This regression in exudate production was not observed in the treated wounds potentially due to the maintenance of moisture provided by the Lanette cream formulations.

The development of granulation was observed from the third day of treatment, with evident occurrence on the fifth day. This analysis was difficult to perform in the control wounds (SS) as the presence of the crust covered the wound (Figure 2E-H). The granulation development was observed microscopically in the samples collected on the seventh day of treatment for all wounds (Figure 3E-H). In addition, lesions of the $\mathrm{BC}$ group were more humid and exudative with maintenance of the fibrin crust and reduction of perilesional oedema.

The comparison of the wound area between treatments demonstrated a significant small area of the lesion in the wounds treated with SS in day 3 and 7. After $14 \mathrm{~d}$ of wounds induction, OR wounds presented a significant small area in comparison with HE wounds. At $21 \mathrm{~d}$ after induction, despite no significant difference, the wounds

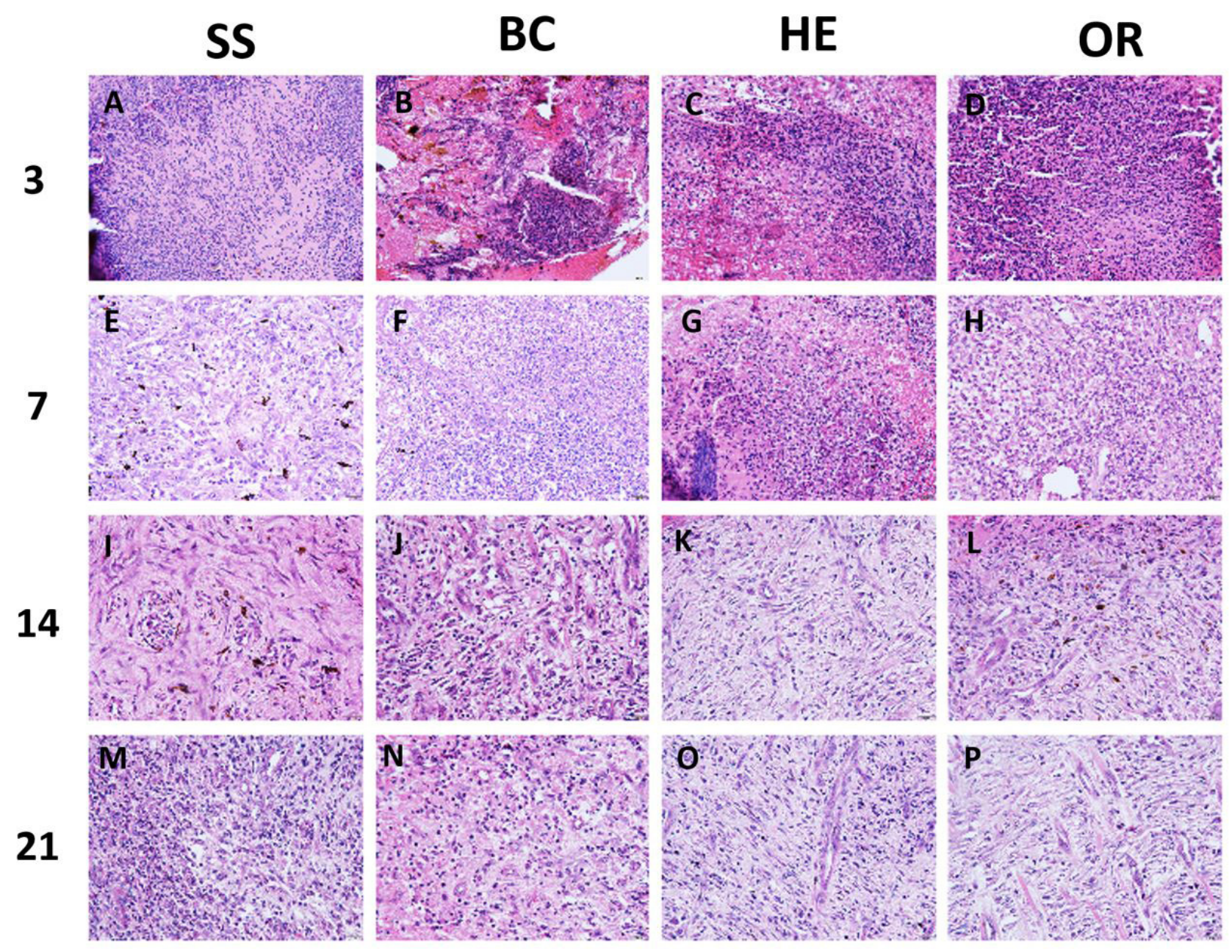

Figure 3 - Cutaneous wounds photomicrographs in the different experimental periods (3, 7, 14 and $21 \mathrm{~d})$. Large number of cells resulting from the local inflammatory process is noted (A-D); increased cellularity in the HE and OR groups (G-H); greater organization of the connective tissue fibers of the HE and OR groups in relation to the others, presenting lower cellularity and important vascularization (K-L); maintenance of the same pattern in $21 \mathrm{~d}(\mathrm{O}-\mathrm{P})$. SS - saline solution; $\mathrm{BC}$ - base cream; HE - hydroalcoholic extract; OR - oil-resin. 
treated with $\mathrm{BC}, \mathrm{HE}$ and $\mathrm{OR}$ presented a smaller area than SS (Table 2 and Figure 4).

In the microscopic analysis, a large number of cells in the region of the lesions of the HE and OR groups was observed due to the acute inflammatory process of wound healing, in addition to an increase in the number of vessels in the HE and OR groups compared to the other periods within the same group (Table 3).

After $14 \mathrm{~d}$ of treatment, the lesions had no fibrinous exudate, and the $\mathrm{BC}$ and $\mathrm{OR}$ groups (Figures $2 \mathrm{~N}$ and $\mathrm{P}$ ) had no crust, whereas the HE group presented a dry crust. In addition, there was total re-epithelialization of the lesions.

The analyses of the biopsies in this period revealed that the total number of cells, local inflammatory infiltrate, and a more typical structuring of the dermis and cellularity was observed compared to the controls (Figure $3 \mathrm{~K}$ and L).
After $21 \mathrm{~d}$ of treatment, it was possible to perceive the absence of a crust and complete re-epithelialization in the lesions of the HE and OR groups (Figure $2 \mathrm{~S}$ and $\mathrm{T}$ ). Microscopically, the dermis was fully organized and exhibited an adequate distribution of the extracellular matrix compared to the other groups (Figure $3 \mathrm{O}$ and $\mathrm{P}$ ).

\section{Discussion}

The objective of this study was to evaluate wound healing in horses subjected to Copaifera langsdorffii treatment. In spite of the fact that wounds are more common in the limb region and that the healing process occurs differently between the limbs and the dorsal region of the equine body (Howard et al., 2019; Hussni et al., 2010; Jacobs et al., 1984; Oliveira et al., 2012; Theoret \& Wilmink, 2013) we opted, as well as other several studies, to use the dorsal

Table 2 - Wound area $\left(\mathrm{cm}^{2}\right)$ in horses on days 1, 3, 7, 14 and 21 of treatment with saline solution, base cream, hydroalcoholic extract, and oil resin of Copaifera langsdorffii. Data is expressed as mean \pm standard deviation (Botucatu- SP, Brazil, 2014)

\begin{tabular}{cccccc}
\hline & \multicolumn{1}{c}{ Day 1 } & \multicolumn{1}{c}{ Day 3 } & \multicolumn{1}{c}{ Day 7 } & \multicolumn{1}{c}{ Day 14 } & Day 21 \\
\hline SS & $3.38 \pm 0.26$ & $2.76 \pm 0.17$ & $2.66 \pm 0.74$ & $1.58 \pm 0.32$ & $0.55 \pm 0.39$ \\
BC & $3.30 \pm 0.27$ & $3.55 \pm 0.39^{* *}$ & $3.94 \pm 0.30^{* * *}$ & $1.67 \pm 0.36$ & $0.36 \pm 0.42$ \\
HE & $3.22 \pm 0.27$ & $3.43 \pm 0.34^{* *}$ & $3.95 \pm 0.46^{* *}$ & $2.26 \pm 0.72 \#$ & $0.32 \pm 0.38$ \\
OR & $3.51 \pm 0.26$ & $3.40 \pm 0.32^{* *}$ & $4.10 \pm 0.35^{* * *}$ & $1.35 \pm 0.68$ & $0.10 \pm 0.13$ \\
\hline
\end{tabular}

SS - saline solution; BC - base cream; HE - hydroalcoholic extract; OR - oil-resin. Data expressed as the mean and standard deviation. $* *$ p $<0.01$ and; $* * * \mathrm{p}<0.001$ with respect to the saline group and; \#p $<0.05$ compared to the test groups HE and OR.

Table 3 - Vessel quantification in skin wounds performed in horses after 3, 7, 14 and $21 \mathrm{~d}$ of treatment. Data is expressed as mean \pm standard deviation (Botucatu- SP, Brazil, 2014)

\begin{tabular}{ccccc}
\hline & Day 3 & Day 7 & Day 14 & Day 21 \\
\hline SS & $7.83 \pm 2.04$ & $11.95 \pm 3.91$ & $21.83 \pm 8.85$ & $14.30 \pm 3.90$ \\
BC & $9.75 \pm 1.71$ & $13.06 \pm 4.73$ & $21.89 \pm 9.09$ & $16.29 \pm 5.50$ \\
HE & $8.00 \pm 1.00$ & $11.68 \pm 3.76$ & $20.94 \pm 7.14$ & $15.13 \pm 5.41$ \\
OR & $9.17 \pm 1.50$ & $13.11 \pm 3.68$ & $19.39 \pm 7.49$ & $13.45 \pm 4.17$ \\
\hline
\end{tabular}

SS - saline solution; BC - base cream; HE - hydroalcoholic extract; OR - oil-resin. Data expressed as the mean and standard deviation. Count in a total area of $100.000 \mu \mathrm{m}^{2}$.

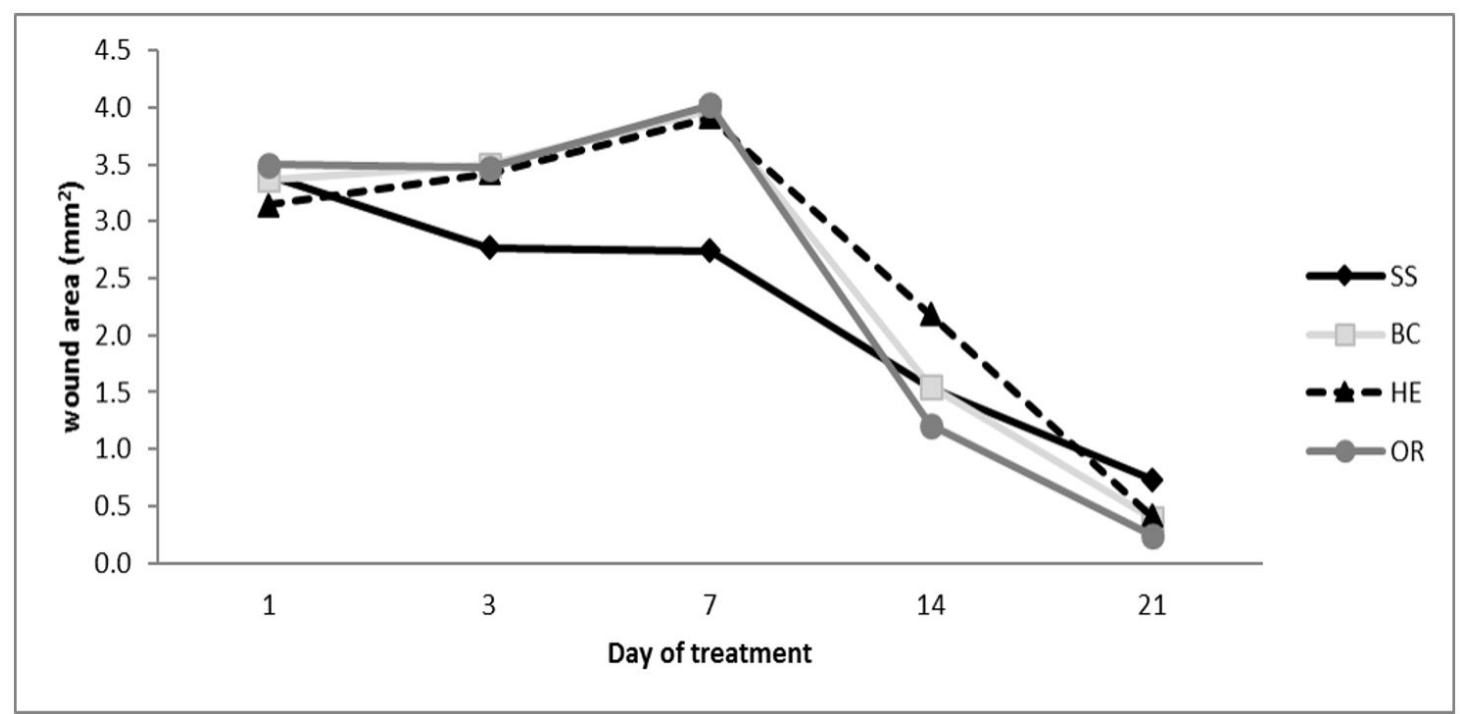

Figure 4 - Wound area $\left(\mathrm{cm}^{2}\right)$ on days 1, 3, 7, 14 and 21 of treatment of skin lesions performed in horses with saline solution (SS), base cream (BC), hydroalcoholic extract (HE), and oil-resin (OR) of Copaifera langsdorffii. 
region of the body to evaluate healing in horses. The use of the lumbar region allowed the achievement of a greater number of wounds per animal, minimized the number of animals required and the environmental contamination of the wounds, facilitated monitoring, and allowed data to be obtained in a shorter time of experimentation.

The wounds were treated with no dressing or protection, although open wounds are more suitable to desiccation and trauma (Kamus et al., 2018; Stashak, 2008). The local environment was kept moist by the application of ointments and the wounds were located dorsally in the body, circumventing this problem. In addition, the non-use of wound protection has the principle to observe the effect of the product without the interference of other aspects.

The difficulty of standardization of the treatment can be considered one limitation of this study, since the saline-treated wounds presented a firmly adhered crust in comparison with the other treatments, where the crust removal was involuntary as a result of ointment hydration. Based on the fact that trauma is one of the main factors that negatively interfere in wound healing (Estevão et al., 2013; Hendrickson \& Virgin 2005), it is believed that the forced removal of crusts in saline solution treatment would be more detrimental to the evaluation of wound healing than maintenance. Crust removal mimics a trauma situation and stimulates healing delay, leading the wound to return to an inflammatory phase.

The Lanette cream formulations and respective concentrations of $\mathrm{HE}$ and OR were based on previous studies (Estevão et al., 2013; Gushiken et al., 2017a, 2017b; Masson Meyer et al., 2013), and showed the biological potential of $\mathrm{HE}$ and $\mathrm{OR}$ in the cutaneous lesions of rats.

As a physiological control of the healing, we used saline isotonic solution, which has been characterized as non-toxic and non-aggressive to scar tissue (Beam, 2006). In horses, an experimental study was performed using $10 \%$ copaiba oil to treat induced skin wounds and presented results that were indicative of its use for the treatment of wounds in this species (Lucas et al., 2017). However, the study addressed only the macroscopic reduction of the lesions and did not report the mechanisms and clinical parameters involved; thus, there is a need for further studies to elucidate the mechanisms of action of this treatment.

The initial bleeding at the time of the accomplishment was considered the initial phase of the wound healing process (Hussni et al., 2004; Mandelbaum et al., 2003). On the third day, wounds treated with saline solution showed perilesional edema, and the lesions treated with $\mathrm{HE}$ did not show edema, although they presented exudation, and the lesions treated with OR were drier and did not present an apparent crust. Interestingly, it is desirable that skin wounds are not exudative, and under treatment, they remained dry. At the same time, biopsies showed a large number of typical lymphocytic infiltrate cells, and abundant cellular debris, consistent with the description of Ribeiro et al. (2013), where the development of perilesional edema was observed from $24 \mathrm{~h}$ to the fourth day of treatment. In a study performed by Lucas et al. (2017) with 10\% copaiba essential oil on wounds in the lumbar and metacarpal regions of horses, a non-exudative repair process was reported, which was consistent with our results after $3 \mathrm{~d}$ of treatment with oil-resin cream. In rats, there was significant activity in the inflammatory mechanism of Copaifera langsdorffii creams (Gushiken et al., 2017b).

The observation of persistent serous exudate production in the wounds treated with $\mathrm{BC}, \mathrm{HE}$ and $\mathrm{OR}$, was not observed in the control group (SS), that presented a serous exudate only until the third day of treatment. This regression in exudate production was not observed in the treated wounds potentially due to the maintenance of moisture provided by the Lanette cream formulations.

The development of granulation from the third day of treatment, with evident occurrence on the fifth day, and microscopically observed on the seventh day of treatment for all wounds is similar to those described in previous studies (Hussni et al., 2004, 2010). In addition, lesions of the $\mathrm{BC}$ group were more humid and exudative with maintenance of the fibrin crust and reduction of perilesional edema, unlike that observed in the use of systemic antiinflammatories, which minimized edema and exudate of the wounds (Hussni et al. 2004, 2010). In the microscopic analysis, we observed a large number of cells in the region of the lesions of the HE and OR groups due to the acute inflammatory process of wound healing, in addition to an increase in the number of vessels in the HE and OR groups compared to the other periods within the same group.

At $14 \mathrm{~d}$ of treatment, there was total re-epithelization of the lesions, no exudate and absence of crust in $\mathrm{BC}$ and OR groups. Microscopically, a reduction of blood vessels in the HE and OR groups was observed. These results were consistent with previous studies using Copaifera langsdorffi in cutaneous lesions of rats by Estevão et al. (2013) and Paiva et al. (2002). Clinically, in horses, the results obtained in this study do not present significant data as in rats, but analyses of the biopsies in this period revealed that the total number of cells and local inflammatory infiltrate and a more typical structuring of the dermis and cellularity was observed compared to the controls.

Although the Lanette cream formulation is currently used as one of the primary moisturizers based on dermatological products in humans, the incorporation of dermatological active principles for experimentation and non-described reactions resulting from its use in humans and potential 
dermatological reactions in horses are unknown, which warrant further study in the use of this commercial formulation for topical treatment.

The use of oil resin can be indicated as an auxiliary product in the treatment of cutaneous wounds in horses and does not interfere in the retraction of the lesion and promotes improvement of healing quality after $7 \mathrm{~d}$ of treatment. The results indicated that is important to develop a new method of dispersion of Copaifera langsdorffii Desf Kuntze (Leguminosae) extract and oil.

New studies are needed to evaluate the use of the oil resin in naturally occurring wounds in different body locations and with different sizes. It is expected that large wounds treated with the oil resin will heal with a more favorable aesthetic aspect. Thus, the study in the lumbar region is an initial phase of future studies and applied in different regions of the horse's body and in different clinical situations.

\section{Conclusions}

Topical treatments of oil-resin and hydroalcoholic extract formulations of copaiba did not reduce healing time within the first $7 \mathrm{~d}$ after surgical wound induction. After 14 and $21 \mathrm{~d}$, the copaiba-based treatments, especially the oil-resin treatment, helped to improve the clinical aspects of the lesions. More studies are needed to elucidate the mechanisms of Copaifera langsdorffi wound healing, but the discovery of oil-resin as an auxiliary product in the treatment of cutaneous wounds in horses is an interesting finding, especially because it does not interfere in wound retraction and improved the healing quality after $7 \mathrm{~d}$ of treatment.

\section{Conflict of Interest}

The authors declare no conflict of interest.

\section{Ethics Statement}

This study was approved by the Ethics Committee on the Use of Animals of the Institute of Biosciences of Botucatu - UNESP (CEUA-IBB 419/12).

\section{Acknowledgements}

Financial support: National Council for Scientific and Technological Development- CNPq (Unesp Institutional Scholarship Program-PIBIC) and São Paulo Research Foundation - FAPESP (grant number \#2011/13630-7 and 2014/23684-5).

\section{References}

Abrão F, Costa LDA, Alves JM, Senedese JM, Castro PT, Ambrósio SR, Veneziani RCS, Bastos JK, Tavares DC, Martins CHG. Copaifera langsdorffii oleoresin and its isolated compounds: antibacterial effect and anti-proliferative activity in cancer cell lines. BMC Complement Altern Med. 2015;15:443-52. PMid:26691920.

Beam JW. Wound Cleansing: water or saline? J Athl Train. 2006;41(2):196-7.

Brancalion APS, Oliveira RB, Sousa JPB, Groppo M, Berretta AA, Barros ME, Boim MA, Bastos JK. Effect of hydroalcoholic extract from Copaifera langsdorffii leaves on urolithiasis induced in rats. Urol Res. 2012;40(5):475-81. http://dx.doi. org/10.1007/s00240-011-0453-z. PMid:22237410.

Cetin EO, Yesil-Celiktas O, Cavusoglu T, Demirel-Sezer E, Akdemir O, Uyanikgil Y. Incision wound healing activity of pine bark extract containing topical formulations: a study with histopathological and biochemical analyses in albino rats. Pharmazie. 2013;68(1):75-80. PMid:23444785.

Corrêa MP. Dicionário de plantas úteis do Brasil e das exóticas cultivadas. Rio de Janeiro: Imprensa Nacional; 1984.
Estevão LRM, Medeiros JP, Baratella-Evêncio L, Simões RS, Mendonça FDS, Evêncio-Neto J. Effects of the topical administration of copaiba oil ointment (Copaifera langsdorffii) in skin flaps viability of rats. Acta Cir Bras. 2013;28(12):8639. http://dx.doi.org/10.1590/S0102-86502013001200009. PMid:24316860.

Funkquist B, Obel N. Fixation of skin grafts in the horse using stainless steel staples. Equine Vet J. 1979;11(2):11721. http://dx.doi.org/10.1111/j.2042-3306.1979.tb01322.x. PMid:383478.

Furtado RA, Bernardes CT, da Silva MN, Zoccal KF, Faccioli LH, Bastos JK. Antiedematogenic evaluation of Copaifera langsdorffii leaves hydroethanolic extract and its major compounds. BioMed Res Int. 2015;2015:913152. http:// dx.doi.org/10.1155/2015/913152. PMid:26078969.

Gál P, Toporcer T, Grendel T, Vidová Z, Smetana K Jr, Dvoránková B, Gál T, Mozes S, Lenhardt L, Longauer F, Sabol M, Sabo J, Backor M. Effect of Atropa belladonna L. on skin wound healing: biomechanical and histological study in rats and in vitro study in keratinocytes, 3T3 fibroblasts, and human umbilical vein endothelial cells. 
Wound Repair Regen. 2009;17(3):378-86. http://dx.doi. org/10.1111/j.1524-475X.2009.00475.x. PMid:19660046.

Gomes NM, Rezende CM, Fontes SP, Matheus ME, Fernandes PD. Antinociceptive activity of Amazonian Copaiba oils. J Ethnopharmacol. 2007;109(3):486-92. http://dx.doi. org/10.1016/j.jep.2006.08.018. PMid:17029841.

Gushiken LFS, Hussni CA, Bastos JK, Rozza AL, Beserra FP, Vieira AJ, Padovani CR, Lemos M, Polizello M Junior, Silva JJM, Nóbrega RH, Martinez ERM, Pellizzon CH. Skin wound healing potential and mechanisms of the hydroalcoholic extract of rats leaves and oleoresin of Copaifera langsdorffii Desf. Kuntze in Rats. Evid Based Complement Alternat Med. 2017a;2017:6589270. http:// dx.doi.org/10.1155/2017/6589270. PMid:28928790

Gushiken LFS, Hussni CA, Bastos JK, Rozza AL, Padovani CR, Takahira RK, Pellizzon CH. Hydroalcoholic Extract from Copaifera Langsdorffii Has Skin Wound Healing Activity in Rats. Int J Complement Altern Med. 2017b;2017:1-7.

Hendrickson D, Virgin J. Factors that affect equine wound repair. Vet Clin North Am Equine Pract. 2005;21(1):33-44. http://dx.doi.org/10.1016/j.cveq.2004.11.002. PMid:15691598.

Howard DJ, Anderson SL, Nahar VK. a preliminary study on second-intention healing of full-thickness wounds on equine distal forelimbs treated with Maltodextrin. J Eq Vet Sci. 2019;74:90-4. http://dx.doi.org/10.1016/j.jevs.2018.12.018.

Hussni CA, Gianini CG, Alves ALG, Nicoletti JLM, Thomassian A, Crocci AJ, Sequeira JL. Cicatrização cutânea por segunda intenção em equinos tratados com vedaprofeno. Arch Vet Sci. 2004;9(1):87-97. http://dx.doi. org/10.5380/avs.v9i1.4051.

Hussni CA, Groh TM, Alves ALG, Crocci AJ, Nicoletti JLM, Watanabe MJ. Efeitos da Fenilbutazona na cicatrização de feridas cutâneas em equinos. Braz J Vet Res Anim Sci. 2010;47(4):262-7. http://dx.doi.org/10.11606/issn.16784456.bjvras.2010.26824.

Jacobs KA, Leach DH, Fretz PB, Townsend HGG. Comparative aspects of the healing of excisional wounds on the leg and body of horses. Vet Surg. 1984;13(2):83-90. http://dx.doi. org/10.1111/j.1532-950X.1984.tb00765.x.

Kamus LJ, Theoret, C, Costa, MC. Use of next generation sequencing to investigate the microbiota of experimentally induced wounds and the effect of bandaging in horses. PLoSONE. 2018;13(11):e0206989.
Lemos M, Santin JR, Mizuno CS, Boeing T, De Sousa JPB, Nanayakkara D, Bastos JK, De Andrade SF. Copaifera langsdorffii: evaluation of potential gastroprotective of extract and isolated compounds obtained from leaves. Brazilian J Pharmacogn. 2015;25(3):238-45. http://dx.doi. org/10.1016/j.bjp.2015.05.005.

Lucas FA, Kandrotas AL, Nardin Neto E, Siqueira CE, André GS, Bromerschenkel I, Perri SHV. Copaiba oil in experimental wound healing in horses. Cienc Rural. 2017;47(4):1-7. http:// dx.doi.org/10.1590/0103-8478cr20151292.

Mandelbaum SH, Di Santis EP, Mandelbaum MHS. Cicatrização: conceitos atuais e recursos auxiliares - Parte I. Na Bras Dermatol. 2003;78(4):393-410. http://dx.doi. org/10.1590/S0365-05962003000400002.

Masson-Meyer D, Enweme S, Violet B, Andrey M. Topical treatment with Copaifera langsdorffi oleoresin improves wound healing in rats. Int J Phytomed. 2013;5:378-86.

Morin C, Roumegous A, Carpentier G, Barbier-Chassefière V, Garrigue-Antar L, Caredda S, Courty J. Modulation of inflammation by Cicaderma ointment accelerates skin wound healing. J Pharmacol Exp Ther. 2012;343(1):115-24. http://dx.doi.org/10.1124/jpet.111.188599. PMid:22767532.

Oliveira JR Jr, Souza VRC, Endringer DC, Hendrickson DA, Coelho CS. Effects of topical application of SunflowerSeed oil on experimentally induced wounds in horses. J Eq Vet Sci. 2012;32(3):139-45. http://dx.doi.org/10.1016/j. jevs.2011.08.006.

Oliveira RB, Coelho EB, Rodrigues MR, Costa-Machado ARM, de Sousa JPB, Berretta AA, Bastos JK. Effect of the Copaifera langsdorffii Desf. leaf extract on the ethylene glycol-induced nephrolithiasis in rats. Evid Based Complement Alternat Med. 2013:131372. http://dx.doi. org/10.1155/2013/131372. PMid:24027592.

Paiva LAF, Cunha KMDA, Santos FA, Gramosa NV, Silveira ER, Rao VSN, Alencar Cunha KM, Santos FA, Gramosa NV, Silveira ER, Rao VSN. Investigation on the wound healing activity of oleo-resin from Copaifera langsdorffi in rats. Phytother Res. 2002;16(8):737-9. http://dx.doi. org/10.1002/ptr.1049. PMid:12458476.

Rennert RC, Rodrigues M, Wong VW, Duscher D, Hu M, Maan Z, Sorkin M, Gurtner GC, Longaker MT. Biological therapies for the treatment of cutaneous wounds: phase III and launched therapies. Expert Opin Biol Ther. 2013;13(11):1523-41. http://dx.doi.org/10.1517/1471259 8.2013.842972. PMid:24093722. 
Ribeiro G, Silva MAG, Martins CB, Borges VP, Lacerda Neto JC. Associação fitoterápica no tratamento de feridas cutâneas induzidas em equinos. Arq Bras Med Vet Zootec. 2013;65(5):1427-33. http://dx.doi.org/10.1590/S010209352013000500022 .

Rittié L. Cellular mechanisms of skin repair in humans and other mammals. J Cell Commun Signal. 2016;10(2):103-20. http://dx.doi.org/10.1007/s12079-016-0330-1. PMid:27170326.

Roy P, Amdekar S, Kumar A, Singh R, Sharma P, Singh V. In vivo antioxidative property, antimicrobial and wound healing activity of flower extracts of Pyrostegia venusta (Ker Gawl). Miers J Ethnopharmacol. 2012;140(1):186-92. http://dx.doi.org/10.1016/j.jep.2012.01.008. PMid:22265749.

Schwartz AJ, Wilson DA, Keegan KG, Ganjam VK, Sun Y, Weber KT, Zhang J. Factors regulating collagen synthesis and degradation during second-intention healing of wounds in the thoracic region and the distal aspect of the forelimb of horses. Am J Vet Res. 2002;63(11):1564-70. http://dx.doi. org/10.2460/ajvr.2002.63.1564. PMid:12428668.

Spaas JH, Broeckx S, Van De Walle GR, Polettini M. The effects of equine peripheral blood stem cells on cutaneous wound healing: A clinical evaluation in four horses. Clin Exp Dermatol. 2013;38(3):280-4. http://dx.doi.org/10.1111/ ced.12068. PMid:23517358.

Stashak TS. Update on wound dressings: indications and best use. In: Stashak TS, Theoreth CL. Equine wound management. 2nd ed. Ames, IA: Wiley Blackwell; 2008. p. 109-36.
Tarameshloo M, Norouzian M, Zarein-Dolab S, Dadpay M, Gazor R. A comparative study of the effects of topical application of Aloe vera, thyroid hormone and silver sulfadiazine on skin wounds in Wistar rats. Lab Anim Res. 2012;28(1):17-21. http://dx.doi.org/10.5625/lar.2012.28.1.17. PMid:22474470.

Theoret CL, Wilmink JM. Aberrant wound healing in the horse: naturally occurring conditions reminiscent of those observed in man. Wound Repair Regen. 2013;21(3):36571. http://dx.doi.org/10.1111/wrr.12018. PMid:23441750.

Tziotzios C, Profyris C, Sterling J. Cutaneous scarring: pathophysiology, molecular mechanisms, and scar reduction therapeutics. J Am Acad Dermatol. 2012;66(1):13-24. http:// dx.doi.org/10.1016/j.jaad.2011.08.035. PMid:22177632.

Upadhyay A, Chattopadhyay P, Goyary D, Mazumder PM, Veer V. Eleutherine indica L. accelerates in vivo cutaneous wound healing by stimulating Smad-mediated collagen production. J Ethnopharmacol. 2013;146(2):490-4. http:// dx.doi.org/10.1016/j.jep.2013.01.012. PMid:23337744.

Veiga VF Jr, Pinto ÂC. O Gênero Copaifera L. Quím. 2002;25(2):273-86.

Financial Support: National Council for Scientific and Technological Development- CNPq (Unesp Institutional Scholarship Program-PIBIC) and São Paulo Research Foundation - FAPESP (grant number \#2011/13630-7 and 2014/23684-5). 